\title{
The Development and Use of Sustainability Criteria in SuRF-UK's Sustainable Remediation Framework
}

\author{
R. Paul Bardos $1,2, *$ (i), Hayley F. Thomas ${ }^{3}$, Jonathan W. N. Smith ${ }^{4,5}$ (i), Nicola D. Harries ${ }^{6}$ (i), \\ Frank Evans ${ }^{7}$, Richard Boyle ${ }^{8}$, Trevor Howard ${ }^{9}$, Richard Lewis ${ }^{10}$, Alan O. Thomas ${ }^{11}$ \\ and Angela Haslam ${ }^{9}$ \\ 1 R3 Environmental Technology Ltd., Reading RG6 6AT, UK \\ 2 School of Environment and Technology, University of Brighton, Brighton BN2 4AT, UK \\ 3 Shell Global Solutions International B.V., 2288GS Rijswijk, The Netherlands; Hayley.thomas@shell.com \\ 4 Shell Global Solutions (UK) Ltd., London SE1 7NA, UK; jonathan.w.smith@shell.com \\ 5 Groundwater Protection \& Restoration Group, University of Sheffield, Sheffield S10 2TN, UK \\ 6 CL:AIRE, London WC1B 3QJ, UK; nicola.harries@claire.co.uk \\ 7 National Grid Property, Warwick CV34 6DA, UK; Frank.Evans@nationalgrid.com \\ 8 Homes England, 2 Rivergate Temple Quay, Bristol BS1 6EH, UK; richard.boyle@homesengland.gov.uk \\ 9 Environment Agency, Bristol BS1 5AH, UK; trevor.howard@environment-agency.gov.uk (T.H.); \\ angela.haslam@environment-agency.gov.uk (A.H.) \\ 10 WSP Remediation, London WC2A 1AF, UK; richard.lewis@wsp.com \\ 11 Environmental Resources Management, Oxford OX2 0QS, UK; alan.thomas@erm.com \\ * Correspondence: paul@r3environmental.co.uk; Tel.: +44-118-378-8164
}

Received: 30 March 2018; Accepted: 18 May 2018; Published: 29 May 2018

\begin{abstract}
Sustainability considerations have become widely recognised in contaminated land management and are now accepted as an important component of remediation planning and implementation around the world. The Sustainable Remediation Forum for the UK (SuRF-UK) published guidance on sustainability criteria for consideration in drawing up (or framing) assessments, organised across 15 "headline" categories, five for the environment element of sustainability, five for the social, and five for the economic. This paper describes how the SuRF-UK indicator guidance was developed, and the rationale behind its structure and approach. It describes its use in remediation option appraisal in the UK, and reviews the international papers that have applied or reviewed it. It then reviews the lessons learned from its initial use and the opinions and findings of international commentators, and concludes with recommendations on how the indicator categories might be further refined in the future. The key findings of this review are that the SuRF-UK framework and indicator guidance is well adopted into practice in the UK. It is widely recognised as the most appropriate mechanism to support sustainability-based decision making in contaminated land decision making. It has influenced the development of other national and international guidance and standards on sustainable remediation. However, there is room for some fine tuning of approach based on the lessons learned during its application.
\end{abstract}

Keywords: contaminated land; sustainable remediation; sustainability assessment; risk management; brownfields; indicators

\section{Introduction}

Despite much progress, significant work remains in tackling the global land contamination legacy and its public health and environmental impacts. A recent study for the European Commission found an annual management cost of contaminated sites in the European Union of $\sim € 3$ billion [1]. A 2012 estimate for overall remediation costs for the known contaminated sites in the USA was \$110-127 
billion [2]. The 2017 global market for environmental remediation technologies is estimated to be US $\$ 68$ billion [3]. These costs represent complex site management effort, and it is important that this effort is made as sustainable as possible.

Contaminated land is managed to mitigate the risks it poses to human health, ecology, water, or other receptors [4]. The international consensus is that risk-based land management provides the best available framework for decisions because (1) it provides an objective way to link actions to the prevention of harm, e.g., to human health or the wider environment; (2) it provides a rationale for how to intervene, i.e., which source-pathway-receptor linkages need to be broken to successfully mitigate unacceptable risks; (3) moreover, it provides a rationale to prioritise limited resources at the most serious/urgent problems/problem sites [5-7]. What sustainable remediation constitutes is sustainable and risk-based management, which broadens the risk management outlook to ensure that reducing the potential for harm from land contamination avoids also unintentional consequences (e.g., emissions to air/water or excessive use of materials and energy), and is also broadly beneficial to society [8].

Over the past 10 years, consequent to the initiation of the first Sustainable Remediation Forum (SURF) in the USA in 2006, sustainability considerations have become more widely recognised in contaminated land management. It is now widely accepted as crucial to remediation planning and implementation around the world [9-12]. Many countries have established sustainable remediation networks which are linked to a central international platform, International Sustainable Remediation Alliance (ISRA), which can be accessed from www.claire.co.uk/isra.

A range of sustainable remediation frameworks and guidance documents have now been published around the world, along with a rapidly growing peer-reviewed journal literature. Sustainable remediation standards have also been published (ASTM, 2013) [13], and most recently ISO, 2017) [14], which consolidates international state of practice on approaches and sustainability assessment in the context of remediation option appraisal [10].

Sustainability is a broad concept which is usually understood by aggregating information about individual indicators $[15,16]$. Sustainability assessment requires a set of individual criteria to be agreed by those carrying out an assessment, which is relevant to the project and stakeholder perspectives.

In 2011 the Sustainable Remediation Forum for the UK (SuRF-UK) published guidance on sustainability criteria (also referred to by SuRF-UK as "indicators") for consideration in drawing up (or framing) assessments, which acts as a checklist. These criteria are organised across 15 "headline" categories, five for the environment element of sustainability, five for the social and five for the economic, as shown in Table 1 [17]. The SuRF-UK indicator checklist remains the most comprehensive and detailed guidance to support the selection of sustainability assessment criteria for sustainable remediation planning and option appraisal from any of the current international sustainable remediation networks [9] and its headline categories are replicated in the ISO Standard [14]. This approach is based on the Brundtland Definition of "sustainable development" [18].

Table 1. SuRF-UK Headline Categories for Indicators [17].

\begin{tabular}{ccc}
\hline Environmental & Social & Economic \\
\hline Emissions to air & Human health and safety & Direct economic costs and benefits \\
\hline Soil and ground conditions & Ethics and equity & Indirect economic costs and benefits \\
\hline Groundwater and surface water & Neighbourhoods and locality & Employment and employment capital \\
\hline Ecology & Communities and community involvement & Induced economic costs and benefits \\
\hline Natural resources and waste & Uncertainty and evidence & Project lifespan and flexibility \\
\hline
\end{tabular}

This paper describes how the SuRF-UK indicator categories were selected, and the rationale behind its structure and approach. It describes its use in remediation option appraisal in the UK, and reviews the international papers that have applied or reviewed it. The paper then reviews the lessons learned from its initial use in the UK and the opinions and findings of international 
commentators, and concludes with recommendations on how the indicator categories might be refined in the future.

\section{The SuRF-UK Framework for Sustainable Remediation}

SuRF-UK is essentially a series of projects supported by a constituency of different practitioners: Regulatory bodies, public agencies, industry and other site owners, consultants and contractors, researchers, developers, and planners. It was established by CL:AIRE after a broad consultation of UK practices in the mid 2000's [19]. CL:AIRE (www.claire.co.uk) is an independent not-for-profit organisation established in 1999, by a number of Public and Private Sector Bodies, to stimulate the regeneration of land in the UK by raising awareness of, and confidence in, practical and sustainable remediation technologies. CL:AIRE have acted as the secretariat for SuRF-UK since its establishment in 2007 to "develop a framework to embed balanced decision making in the selection of a remediation strategy to address land contamination, as an integral part of sustainable development". It has been supported by a Steering Group over this period, whose current membership are the authors of this paper.

In 2010, SuRF-UK published a framework for assessing the sustainability of soil and groundwater remediation [20], which was accepted by all the relevant UK national regulatory and other public bodies. This document defines sustainable remediation as "the practice of demonstrating, in terms of environmental, economic and social indicators, that the benefit of undertaking remediation is greater than its impact, and that the optimum remediation solution is selected through the use of a balanced decision making process". The framework, shown in Figure 1, identifies two stages where sustainability assessment for remediation can influence decision making. These are during project conceptualisation and design (for example, when considering the layout of a site and how it will be used post-remediation; called "Stage A" in the framework), which is when risk management requirements and hence remediation objectives are set; and also after remediation objectives have been set ("Stage B") when the decision is about finding the optimal means of reaching a given set of defined remediation objectives. It is widely thought that the earlier sustainable remediation design can be considered in this decision making process, the greater the chance for greater sustainability "gains" [21,22].

Clearly, to "manage" the sustainability of remediation, i.e., to compare and select the optimal remediation solution, and then to determine how to verify its performance, some form of sustainability assessment is required. SuRF-UK's approach has been to suggest that these decisions should be based on the simplest form of sustainability assessment that produces a reliable management decision, and that in most cases a qualitative assessment is sufficient [23]. If qualitative assessment indicates no clear preferred remediation option, or is questioned by one or more stakeholders then it may be necessary to go for a semi-quantitative approach (i.e., one based on scorings and weightings). Fully quantitative approaches, such as a (monetised) cost benefit assessment, would only be needed if the semi-quantitative assessment also fails to find a resolution. This tiered approach is illustrated in Figure 2. However, as sustainability assessment progresses through these tiers it can lose both transparency (for example because of embedded approximations and assumptions) and have a reduced scope (as analyses cover a smaller range of sustainability considerations) [22]. In particular, cost-benefit analyses may suffer from a number of difficulties relating to transparency, scope, and the reliability of the valuation process, and may therefore not be persuasive to all stakeholders [24]. Furthermore, valuations may be complex and technically challenging [25]. Stakeholder dialogue and engagement is recognised in the SuRF-UK Framework as a key element in developing robust sustainability assessments, not least because there is no such thing as an absolute and objective measurement of sustainability. Processes of engagement and dialogue are explicitly included in SuRF-UK's more detailed guidance on sustainability assessment [26]. Another important facet of achieving sustainability is good working practices on site. This is explicitly recognised in Figure 2 as "Tier 0" for sustainable management procedures, for which detailed guidance has also been developed by SuRF-UK [27]. 


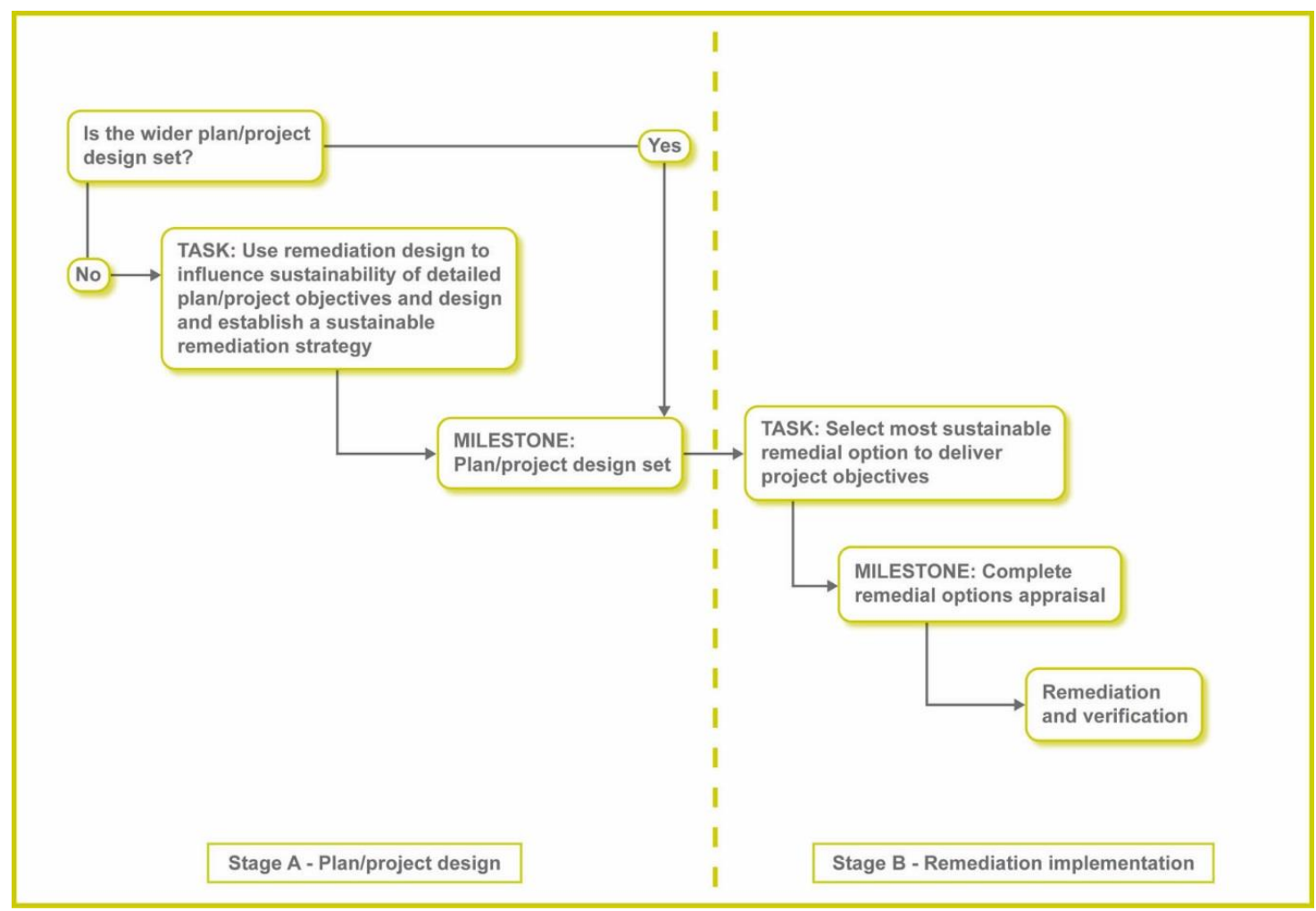

Figure 1. Overall schematic of the SuRF-UK Framework (C CL:AIRE 2010 [20]). Reproduced with permission.

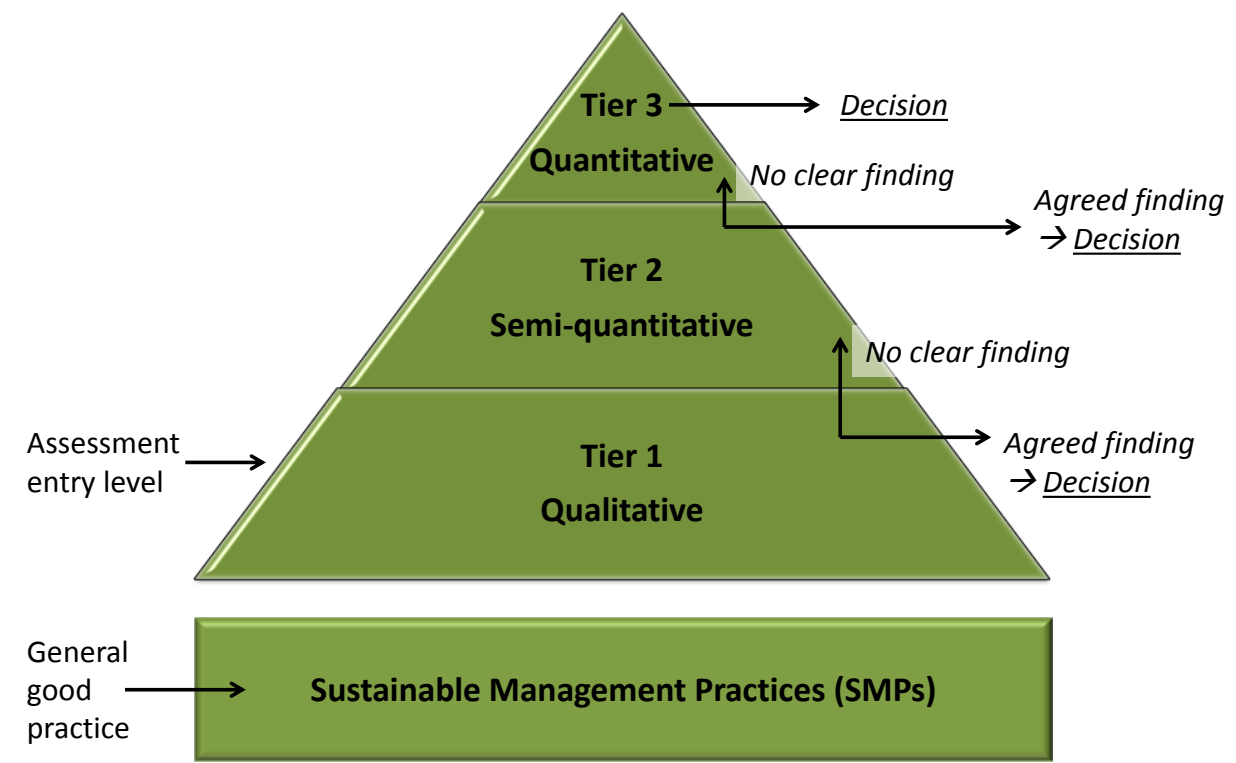

Figure 2. A tiered approach to sustainability assessment (C CL:AIRE 2014 [26]). Reproduced with permission.

In 2014, SuRF-UK released more detailed guidance on how to "frame" and carry out sustainability assessment using its framework, including a summary briefing [26] and downloadable presentations and templates, all freely available from www.claire.co.uk/surfuk. The framing of the sustainability assessment consists of two stages: Preparing the assessment, and defining how it will take place (Figure 3). These stages must be clear and robust before sustainability assessment is carried out to ensure a reproducible sustainability assessment approach. This three-step approach is in line with good practice for sustainability appraisal in the UK planning and development sector [28]. The assessment 
may be iterative, for example, to include wider stakeholder opinions and perspectives as a project progresses. Particularly important in the definition of the sustainability assessment approach is documenting an agreed set of boundaries and an agreed scope that applies to all the options being compared to ensure like is compared with like. SuRF-UK sustainability indicators are key in forming a common understanding of the meaning and scope of each indicator, and its potential overlap with others. To date, none of the other national sustainable remediation initiatives have published a similar checklist [10], although some, such as SuRF-ANZ have adopted it. The US Environmental Protection Agency (EPA) has published guidance on assessing what it terms "Green Remediation" [29], which is broadly in line with the environmental headline categories SuRF-UK has identified (shown in Table 1).

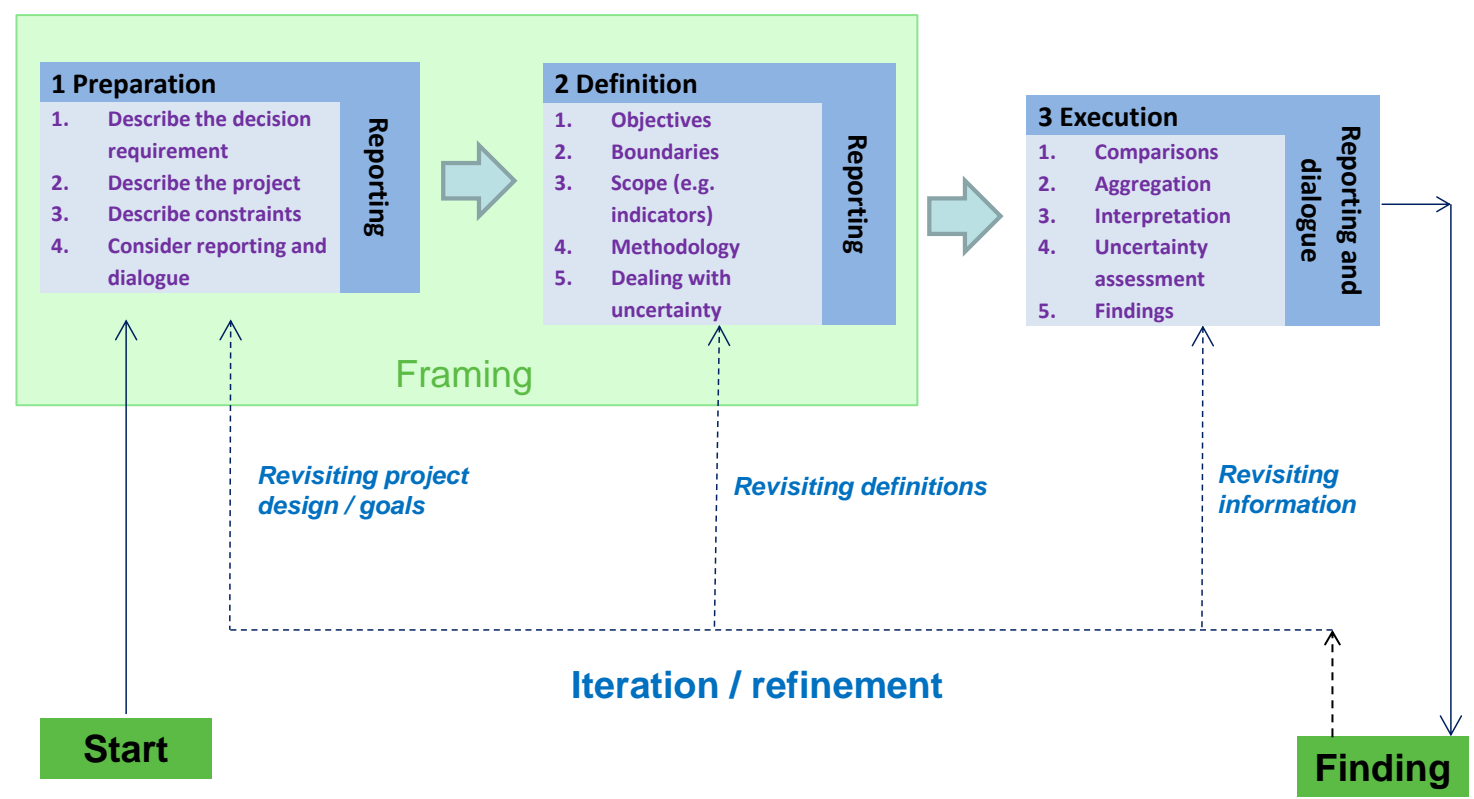

Figure 3. Sustainability assessment and its framing (C CL:AIRE 2014 [26]). Reproduced with permission.

Green remediation, as defined by the US EPA, is a concept based on the wider environmental impacts of remediation, and is predicated on the view that under the US Federal Superfund Program issues relating to economic and social sustainability will already have been considered prior to a remediation decision [9]. Attempts have been made to reconcile this with the wider and more complete domain of sustainable remediation by using the term "Green and Sustainable Remediation" (GSR) [12], albeit some leading advocates consider this term inappropriate [10], for instance because "sustainable remediation" already encompasses the "green" or environmental element of sustainability. The focus of this paper, however, is on the indicator guidance SuRF-UK has developed for the wider domain of sustainable remediation as defined above.

\section{The Development of SuRF-UK's Indicator Guidance}

SuRF-UK's development of guidance on sustainability assessment indicators/guidance began in 2009 when it published a review of a large number of sustainability indicator sets and their relevance to contaminated land management [30]. Over 100 documents describing sustainability indicators (for a wide variety of purposes) were identified and reviewed and a total of 2421 individual indicators were identified, which were mapped to 18 broad headlines, six for each of three elements of sustainability. Within this body of work, no pre-existing and comprehensive set of sustainability indicators/criteria explicitly for contaminated land management was found. Twelve indicator sets (with 265 indicators in total) ascribed to contaminated land management were found. However, the coverage of these indicator sets on an individual basis across the 18 broad categories was incomplete. For example, eight indicator sets did not include consideration of impacts on soil. It was not clear why this should be, 
and SuRF-UK considered this a significant deficit. From an early stage, soil and ground function was seen as a critical category of sustainability by SuRF-UK, which was and is consistent with current policy. In 2017, the Food and Agriculture Organisation of the UN (FAO) published Voluntary Guidelines for Sustainable Soil Management [31], in line with the UN Sustainable Development Goals or SDGs, discussed below. The importance of soils to sustainable development, and the potential threats to good soil function, are also highlighted by the European Soil Thematic Strategy [32], the UK Department for Environment, and Food and Rural Affairs (DEFRA) Soil Strategy for England [33], and are seen as underpinning at least nine of the UN SDGs [34]. Clearly these relate to soils not sealed by buildings or infrastructure. However, in the case of construction that seals soil, re-use of brownfield land reduces the sealing of soils on virgin sites, which is seen as an increasing concern across Europe $[35,36]$.

Initial suggestions for sustainability indicators for remediation were put forward at an open stakeholder meeting in 2008 [19]. These suggestions were fairly evenly distributed across the three elements of sustainable development (environmental, economic, and social). However, within each element, most indicator choices were clumped around particular choices, which were strongly related to landowner and regulator interests (impacts on air, resource utilisation and waste management, indirect and direct costs, community involvement and satisfaction, human health, and impacts on neighbourhoods or regions). The indicators identified by the literature review were wider ranging in the aspects they covered.

SuRF-UK's conclusions from these exercises were that, firstly, there was no "off the shelf" set of sustainability criteria that it could deploy to the support the framework it was developing. Secondly, there was a stakeholder appetite for holistic sustainability assessment for remediation projects, but an incomplete understanding of the full scope of what sustainability assessment might cover. Thirdly, an initial indicator guidance or checklist could be developed from its review of existing sustainability assessment indicator guidance and indicator sets.

Therefore, as an interim position, the 2010 framework document [20] included an initial categorisation list (18 broad categories) used to group indicators for the purposes of cross-comparison in the 2009 review report [30]. Work to develop and refine indicator guidance to support the Framework continued over 2010-2011. SuRF-UK held three open meetings at different locations in the UK, which were attended in total by over 100 practitioners of different types (site managers, consultants, contractors, public agencies, and academics) [19]. Each workshop used a series of three case studies of sustainability assessments for remediation option appraisal using a range of methods and indicators (the same for each workshop), which were then discussed and debated by the delegates. These exercises were used to get a practitioner view on sustainability assessment, including the selection of sustainability indicators/criteria. These were collated and adapted in a spreadsheet checklist, based on one already used for one of the case studies. The spreadsheet checklist was reviewed and refined regularly at a series of Steering Group meetings over 2010/11, and published in 2011 [17]. One of the most substantive changes from the 2010 outline position in the Framework document [20] was the rationalisation of headline categories, reducing these from 18 to 15, five per element of sustainability (environmental, social and economic). The distribution of an equal number of headline categories for each element of sustainability was deliberate, to clearly communicate that no one element was a dominant consideration.

The SuRF-UK indicator guidance is advisory. The headline indicator categories and checklist of individual considerations relate to both relative benefits and relative detriments.

The consultation work that supported its development also showed a clear preference from the UK practitioner community that they did not think a definitive set of criteria would be helpful, as sustainability is highly specific to site, project, and the stakeholders involved. Instead, what is offered is a checklist to assist assessors in defining a broad scope, reminding them what they might be omitting, but not demanding particular criteria should be included. This checklist was supplemented in 2014 with a package of guidance measures about how to frame and carry out sustainability assessment, which provided further advice on how to use the checklist [26]. This included the suggestion that the 
optimum way to use the checklist was to assume any consideration listed is relevant unless there is clear evidence or reasoning to the contrary, agreed by all the stakeholders involved in the assessment. The reasons for non-inclusion should be recorded. Equally, it is possible that the checklist does not include a consideration that stakeholders involved with a particular assessment feel is necessary. In this case it is suggested that the consideration should be included, again with a rationale recorded.

\section{Practical Use of SuRF-UK's Indicator Guidance within the UK}

The SuRF-UK Framework is now in regular use in the UK, as it is cited in a number of guidance documents related to remediation option appraisal, in particular [37,38], as well as there being a strong presumption to sustainable development in wider planning policy [39-41]. Three case studies are provided on the SuRF-UK web site, all relatively early examples:

- Case Study 1-Sustainability Assessment: Former fuel depot, Madeira [42] which used seven of the headline categories as indicators, weighting the others to zero.

- Case Study 2-Upper Heyford-Remediation Options Appraisal [43], which used the 15 headline categories as indicators in combination with technical feasibility scores as a basis for remedy selection.

- Case Study 3-Helpston Contaminated Land Project [44], which used seven of the headline categories as indicators.

Table 2 lists other UK examples of the use of the SuRF-UK framework, including the use of the indicator guidance. This table was collated by the SuRF-UK Steering Group on the basis of published information, grey literature, and the authors' knowledge of UK industry activity. Some of this information was unpublished and intentionally anonymised. Guidance published by UK regulators means that all contaminated land remediation decision making should consider the sustainability of the measures being put in place. In practice site owners, service providers, and site managers will look to established approaches shared by a community of interests, especially if related to a standard, as this is an easier platform for achieving consensus. Therefore, while it is not possible to indicate what proportion of UK projects across the whole contaminated land management sector are represented by Table 2, the listing is substantial, and part of a general trend to consider sustainable remediation. 
Table 2. UK examples of SuRF-UK framework use.

\begin{tabular}{|c|c|c|}
\hline Project Name & Location & How SuRF-UK Framework Was Applied and How Indicators Were Considered \\
\hline Port Sunlight Riverside Park appraisal & Port Sunlight (Merseyside) & $\begin{array}{l}\text { Retrospective investigation of the sustainability gain from establishing a public park on a } \\
\text { former landfill site. The checklist was used in detail to develop a conceptual site model of } \\
\text { sustainability and sustainability assessment against a hypothetical baseline [45]. }\end{array}$ \\
\hline NanoRem UK case study & South England & $\begin{array}{l}\text { Comparison of nanoremediation with other in situ methods for remediation of an } \\
\text { organics contaminated site. They considered all } 15 \text { headline categories and used the } \\
\text { checklist to support this broad category comparison [46]. }\end{array}$ \\
\hline Retail filling station \#1 & Eastern England & $\begin{array}{l}\text { Sustainability assessment of electrokinetic bioremediation compared with alternative } \\
\text { remediation options for a petroleum release site [47]. }\end{array}$ \\
\hline Retail filling station \#2 & Central England & $\begin{array}{l}\text { A benchmarking study compared sustainability assessments across all tiers of } \\
\text { sustainability assessment (qualitative, semi-quantitative and quantitative) using the full } \\
\text { range of SuRF-UK headline indicators. Rankings were generally consistent across the } \\
\text { three methods [48]. }\end{array}$ \\
\hline Retail filling station \#3 & Eastern England & $\begin{array}{l}\text { Sustainability assessment undertaken, including participatory stakeholder session, } \\
\text { to inform best remediation strategy at a site regulated under Part 2A of the } \\
\text { Environmental Protection Act } 1990 \text { [Contaminated Land regime]. }\end{array}$ \\
\hline $\begin{array}{l}\text { Using a hybrid LCA method to evaluate } \\
\text { the sustainability of sediment } \\
\text { remediation }\end{array}$ & London Olympic Park & $\begin{array}{l}\text { This study combined life cycle assessment with the use of a quantitative assessment of } \\
\text { social and economic indicators, based on the SuRF-UK indicator set, to rank options for } \\
\text { the management of dredged materials [49]. }\end{array}$ \\
\hline Environment Agency & England & $\begin{array}{l}\text { Consideration of the SuRF-UK framework and supporting information has been } \\
\text { incorporated into corporate procedures and guidance on regulating the management of } \\
\text { land contamination. This includes references in internal guidance on dealing with } \\
\text { consultations on planning documents and external guidance (e.g., refernce [37]). }\end{array}$ \\
\hline $\begin{array}{l}\text { International Oil Company-National } \\
\text { retail filling station network }\end{array}$ & UK & $\begin{array}{l}\text { Routine application of the SuRF UK indicator set within sustainability assessment for } \\
\text { remedial technologies identified as feasible during remedial alternatives assessments. }\end{array}$ \\
\hline Multinational company & UK & $\begin{array}{l}\text { Use of SuRF-UK SMP checklist resulted in program-wide decisions to: direct all } \\
\text { hydrocarbon-contaminated soils to waste treatment facilities (zero landfill); } \\
\text { apply (and measure) } \mathrm{CO}_{2} \text { reduction objectives to remediation projects; } \\
\text { better planning/combining of fieldwork to minimise road-miles. }\end{array}$ \\
\hline
\end{tabular}


Table 2. Cont

Multi-national utility company

Multinational Manufacturing Client

UK

\begin{tabular}{cc}
\hline Multinational Company & Northern England \\
\hline Multinational Company & Southern England \\
\hline Multinational Company & Northern England \\
\hline Various & UK \\
\hline Multinational Company & $\begin{array}{c}\text { UK, Europe, the Middle } \\
\text { East and Africa }\end{array}$ \\
\hline
\end{tabular}

Multinational Chemical Manufacturer
Established a set of Sustainable Management Practices that all on-site land regeneration activities in UK are required to be evaluated against, in order to embed sustainable decision making into all activities irrespective of scale. This approach is based on SuRF-UK Toolkit SMP practices and Indicator set.

Use of SuRF-UK indicator sets to populate multi-criteria assessment to support remediation evaluation of former chemical processing site. The objective of the assessment was to further develop technological options appraisal whilst developing close out objectives based upon measurable factors.

Application of SuRF-UK guidance through lifecycle of a remediation project. SuRF-UK indicator set used to compare remedial alternatives.

SuRF-UK indicator set used in remedial options appraisal using a mixture of qualitative and quantitative scoring for individual applicable indicators.

Use of SuRF-UK indicator set as basis for a multi criteria analysis of remedial options undertaken in context of a roundtable workshop with key stakeholders for the remedial options appraisal at a manufacturing site.

Routine application of the SuRF UK indicator set within sustainability assessment for remedial technologies identified as feasible during remedial alternatives assessments.

Consideration of SuRF-UK indicator set together with a number of corporate sustainability metrics to develop a broader sustainability assessment across a portfolio of sites. Encouraged and tracked use of SMPs at every stage of the project life cycle.

Use of SuRF-UK indicator sets to populate multi-criteria assessment to support remediation evaluation of former chemical processing site. The objective of the assessment was to further develop technological options appraisal whilst developing close out objectives based upon measurable factors. 


\section{Benchmarking SuRF-UK's Indicator Guidance}

In 2015, the United Nations published a series of 17 Sustainable Development Goals (SDGs), representing an intergovernmental consensus and integrated list of 169 sustainability targets [50]. Table 3 maps these UN SDGs to the SuRF-UK indicator categories. There are direct linkages to 13 of the 17 SDGs. It is not surprising that there are no direct linkages to some, but there are indirect linkages as explained below:

- Goal 1: End poverty in all its forms everywhere-there is an indirect association between this goal and sustainable remediation across many of the SuRF-UK headline categories in that (a) a more efficient land cycle can provide a wide range of wider economic benefits (ECON1/2/3-see Table 3 for explanation of these abbreviations), including stimulating inward investment (ECON4). It is not uncommon for areas in the vicinity of industrial and brownfield sites to be relatively poor [51] and the removal of blight can improve both their health (SOC1) and the local circumstances (SOC3), although "green gentrification" is becoming an emerging concern [52] (SOC2).

- Goal 10: Reduce inequality within and among countries-sustainable remediation assessments tend to be site based. However, the framework created has important considerations that could also be drawn at national/regional level (SOC5).

- Goal 14: Conserve and sustainably use the oceans, seas and marine resources for sustainable development -Marine resources have not been explicitly listed in the "Annex 1" guidance. However, they could be a material consideration at coastal sites, in which case stakeholders can, if they wish, extend the ENV3 category to consider them.

- Goal 17. Strengthen the means of implementation and revitalize the Global Partnership for Sustainable Development-The UN SDGs are not (as yet) referenced in the SuRF UK Indicator guidance. However, the existence and work of SuRF-UK, as well as similar fora in many other countries, advances sustainability in contaminated land management worldwide.

Table 3. SuRF-UK headline categories [18] mapped against examples of potentially-corresponding UN SDGs [50].

\begin{tabular}{ccl}
\hline SuRF-UK Category & Related SDG(s) & $\begin{array}{l}\text { Example Relationships of the SuRF-UK } \\
\text { Sustainability Categories with the UN SDG }\end{array}$ \\
\hline $\begin{array}{c}\text { Emissions to air } \\
\text { (ENV1) }\end{array}$ & $\begin{array}{l}\text { Greenhouse gas emissions are an explicit } \\
\text { consideration in ENV1. }\end{array}$ \\
$\begin{array}{c}\text { Soil and ground } \\
\text { conditions (ENV2) }\end{array}$ & $\begin{array}{l}\text { Some contaminated sites are treated for "soft" re-use } \\
\text { e.g., biofeedstocks reducing land use conflict with } \\
\text { agriculture [53]. }\end{array}$ \\
$\begin{array}{c}\text { Groundwater and } \\
\text { surface water (ENV3) }\end{array}$ & $\begin{array}{l}\text { Improvement of water resources by reducing risks } \\
\text { from contamination. }\end{array}$ \\
\hline Ecology (ENV4) & $\begin{array}{l}\text { Restoration and protection of ecological system } \\
\text { services on brownfield sites, in particular in soil and } \\
\text { water. }\end{array}$ \\
\hline
\end{tabular}


Table 3. Cont.

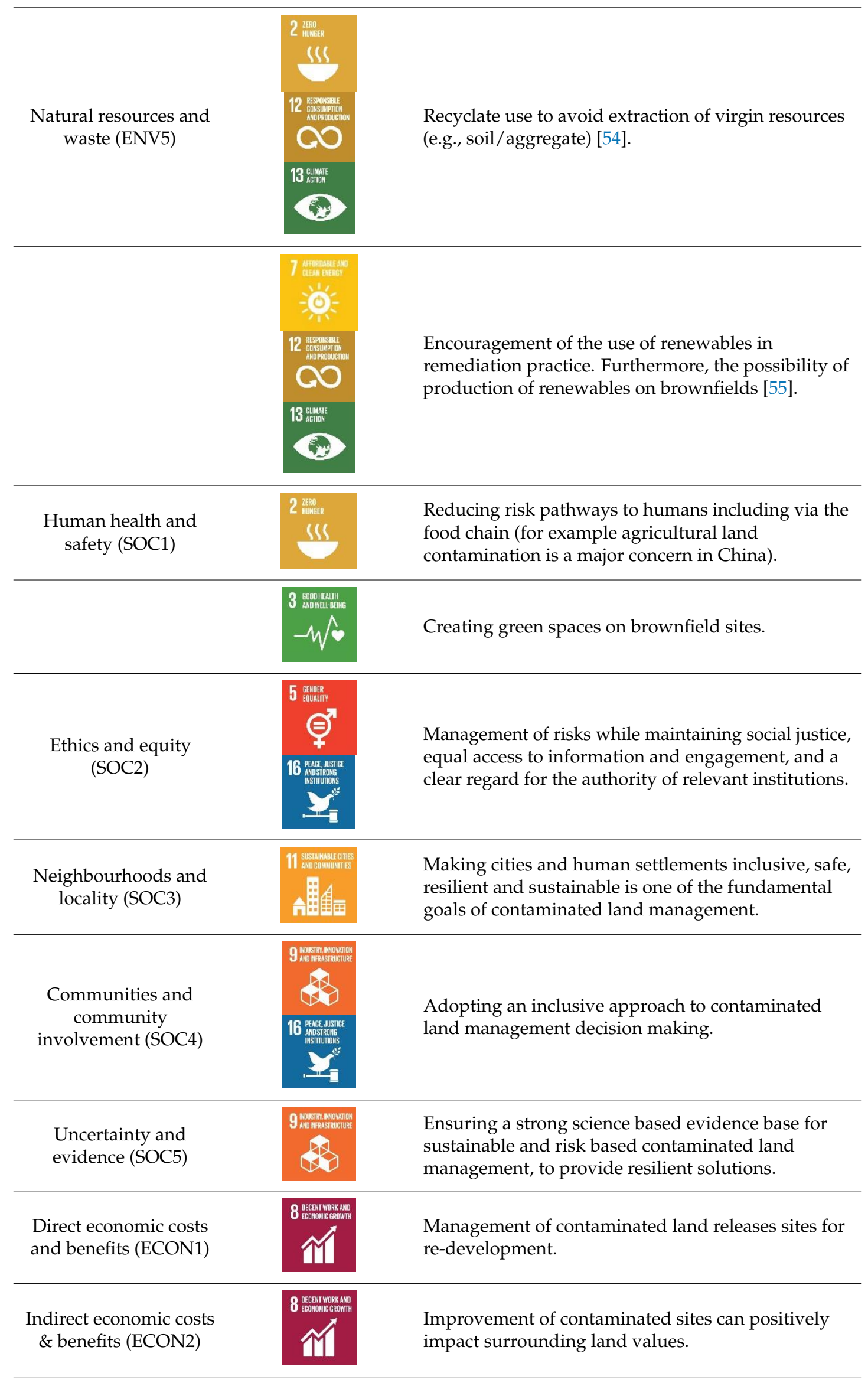


Table 3. Cont.

\begin{tabular}{c}
$\begin{array}{c}\text { Employment \& } \\
\text { employment capital } \\
\text { (ECON3) }\end{array}$ \\
$\begin{array}{c}\text { Induced economic } \\
\text { costs \& benefits } \\
\text { (ECON4) }\end{array}$ \\
$\begin{array}{c}\text { Improvement of amenity and stimulation of } \\
\text { Project lifespan \& } \\
\text { investment by brownfields restoration. } \\
\text { and also more widely (e.g., reference [56]). }\end{array}$ \\
\hline $\begin{array}{l}\text { Ensure remediation solutions are resilient, robust } \\
\text { and flexible over time. }\end{array}$
\end{tabular}

The SuRF-UK indicator categories and checklist highlight a number of wider sustainability considerations, for example relating to ozone depletion and acid rain (ENV1) that are not clearly visible in the UN SDGs, but nonetheless considered very important.

Since 2011, there has been significant activity in the development of general sustainability assessment and associated indicator sets, including the revised UN SDGs and also the OECD well-being indicators [57]. Since the publication of the SURF-UK indicator guidance there have been a number of studies related to the sustainability of brownfields regeneration (e.g., references [58-61]), and cost-benefit and life-cycle based remediation assessments (e.g., references [62,63]) as well as multi-criteria analysis based tools for remediation option appraisal (e.g., references [64,65]). In addition, the USA SURF and the Austrian Environmental Protection Agency published suggested (quantitative) metrics for remediation sustainability assessment [65-67]. Unsurprisingly, none of these represent a substantial digression from the broad scope of sustainability headlines considered by SuRF-UK, but close consideration may offer opportunities for incremental improvement.

\section{Applications of the SuRF-UK Indicator Guidance Worldwide}

In addition to the applications of the SuRF-UK indicator guidance in the UK, it has also been influential on a more global basis. Table 4 lists a number of these applications. This listing was compiled from an open search of published information, for example available from Google Scholar, collated to March 2018.

Table 4. Use of the SuRF-UK indicator guidance worldwide.

\begin{tabular}{lll}
\hline Country/Region & \multicolumn{1}{c}{ Application } & \multicolumn{1}{c}{ Comments } \\
\hline & $\begin{array}{l}\text { An academic study of how different } \\
\text { groups of stakeholders perceive different } \\
\text { values for remediation, and that these can } \\
\text { change as a project progresses, which took } \\
\text { place across four case studies [68]. }\end{array}$ & $\begin{array}{l}\text { Sees the SuRF-UK guidance as industry } \\
\text { led, and emphasises the importance of } \\
\text { social considerations and effective } \\
\text { communication in robust community } \\
\text { engagement in decision making. }\end{array}$ \\
\hline \multirow{2}{*}{ Australia 2015 2016} & $\begin{array}{l}\text { Development of a simple } \\
\text { semi-quantitative method for remediation } \\
\text { sustainability evaluation based on } \\
\text { Australian and overseas practice and } \\
\text { experience [69]. }\end{array}$ & $\begin{array}{l}\text { SuRF Australia/NZ drew on the } \\
\text { SuRF-UK framework and subsequent } \\
\text { documents [70]. This short article } \\
\text { describes a case study sustainability } \\
\text { assessment using the SuRF-UK indicators. }\end{array}$ \\
\hline
\end{tabular}


Table 4. Cont.

\begin{tabular}{|c|c|c|}
\hline Australia 2017 & $\begin{array}{l}\text { Academic review of uncertainties in } \\
\text { remediation and their communication } \\
\text { between experts and non-experts [71]. }\end{array}$ & $\begin{array}{l}\text { Focuses on the social element of the } \\
\text { SuRF-UK Indicator set and suggested that } \\
\text { a potential limitation is a focus on } \\
\text { empirical uncertainty rather than its } \\
\text { "mental" form, which appears to refer to } \\
\text { how uncertainty is represented to } \\
\text { non-experts. }\end{array}$ \\
\hline Belgium 2014 & $\begin{array}{l}\text { Research paper evaluating a range of } \\
\text { sustainability appraisal tools for } \\
\text { remediation option appraisal. The tools } \\
\text { assessed were quantitative in nature and } \\
\text { narrower in scope that the SURF-UK } \\
\text { checklist [72]. }\end{array}$ & $\begin{array}{l}\text { Several operational tools were } \\
\text { benchmarked against each other and the } \\
\text { SuRF-UK Indicator set. The SuRF-UK } \\
\text { guidance is not classed as a tool in this } \\
\text { paper which is in line with its checklist } \\
\text { functionality. }\end{array}$ \\
\hline Belgium 2016 & $\begin{array}{l}\text { Inclusion of social indicators in decision } \\
\text { support tools for the selection of } \\
\text { sustainable site remediation options [73]. } \\
\text { This work found an imbalance of used } \\
\text { indicators still expressing a strong } \\
\text { preference for the environmental aspect at } \\
\text { the expense of the economic and social } \\
\text { aspects of sustainability, the lack of } \\
\text { consistency in the terminology used } \\
\text { within the field and the failure in } \\
\text { adapting released tools to recent } \\
\text { legislation or scientific advancements [74]. }\end{array}$ & $\begin{array}{l}\text { These papers benchmarked the } \\
\text { considerations of five sustainability based } \\
\text { decision support tools against the social } \\
\text { element of the SuRF-UK indicator set, as a } \\
\text { broad ranging schema. }\end{array}$ \\
\hline Brazil 2017 & $\begin{array}{l}\text { Use of the SuRF-UK Framework and } \\
\text { sustainability assessment tools for a } \\
\text { contaminated area of the University of } \\
\text { São Paulo [75]. }\end{array}$ & $\begin{array}{l}\text { Operational activities focused on the } \\
\text { implementation of Sustainable } \\
\text { Management Practices [27] rather than } \\
\text { use of indicators in option appraisals. }\end{array}$ \\
\hline China 2013 & $\begin{array}{l}\text { Book chapter that discusses land } \\
\text { remediation mechanisms in the US and } \\
\text { UK, and how these mechanisms may } \\
\text { apply in China [76]. }\end{array}$ & $\begin{array}{l}\text { Discusses how the SuRF-UK sustainability } \\
\text { framework and indicators might be useful } \\
\text { in the Chinese remediation context. }\end{array}$ \\
\hline China $2016^{*}$ & $\begin{array}{l}\text { UK advice on risk management decision } \\
\text { making, verification of remediation } \\
\text { outcomes, systems of governance and } \\
\text { evaluation of costs versus benefits and } \\
\text { overall sustainability [77]. }\end{array}$ & $\begin{array}{l}\text { Use of the SuRF-UK sustainability } \\
\text { assessment. Subsequent to this work, a } \\
\text { SuRF-China was established in } \\
\text { October } 2017 .\end{array}$ \\
\hline China 2017 & $\begin{array}{l}\text { China has an extensive agricultural land } \\
\text { degradation issue due to pollution. This } \\
\text { paper suggests an approach for a Chinese } \\
\text { sustainability assessment framework for } \\
\text { agricultural land remediation [78]. }\end{array}$ & $\begin{array}{l}\text { Inclusion of SuRF-UK indicators into a } \\
\text { suggested indicator set for use in } \\
\text { sustainable remediation appraisal in } \\
\text { China. }\end{array}$ \\
\hline China 2018 & $\begin{array}{l}\text { Environmental and socio-economic } \\
\text { sustainability appraisal of contaminated } \\
\text { land remediation strategies: A case study } \\
\text { at a mega-site in China [79]. }\end{array}$ & $\begin{array}{l}\text { This suggested sustainability assessment } \\
\text { indicator set was based on the SuRF-UK } \\
\text { indicator set and other sources. However, } \\
\text { the authors felt that the SuRF-UK } \\
\text { indicators were too broad so proposed a } \\
\text { narrower set. }\end{array}$ \\
\hline Colombia 2017* & $\begin{array}{l}\text { Sustainability assessment as a tool in } \\
\text { contaminated site/brownfield } \\
\text { rehabilitation options [80]. }\end{array}$ & $\begin{array}{l}\text { Use of the SuRF-UK sustainability } \\
\text { assessment. }\end{array}$ \\
\hline CZ and UK $2016^{*}$ & $\begin{array}{l}\text { NanoRem Project (www.nanorem.eu). } \\
\text { Site based sustainability assessments of } \\
\text { nanoremediation compared with } \\
\text { alternatives [46]. }\end{array}$ & $\begin{array}{l}\text { Use of the NICOLE Sustainable } \\
\text { Remediation Road Map [81] and the } \\
\text { SuRF-UK sustainability assessment } \\
\text { procedure. }\end{array}$ \\
\hline
\end{tabular}


Table 4. Cont.

\begin{tabular}{|c|c|c|}
\hline Denmark 2016 & $\begin{array}{l}\text { Short review of approaches for assessing } \\
\text { sustainable remediation, commenting on } \\
\text { the limited availability of worked case } \\
\text { studies. }\end{array}$ & $\begin{array}{l}\text { Reproduces the SuRF-UK } 2011 \text { indicator } \\
\text { guidance headline categories [82]. }\end{array}$ \\
\hline Denmark 2017 & $\begin{array}{l}\text { Multi-criteria assessment tool for } \\
\text { sustainability appraisal of remediation } \\
\text { alternatives for a contaminated site [83]. }\end{array}$ & $\begin{array}{l}\text { Inclusion of SuRF-UK indicator } \\
\text { considerations. }\end{array}$ \\
\hline EU FP7 Project $2014 *$ & $\begin{array}{l}\text { Work on the assessment and design of soft } \\
\text { reuse interventions and services within } \\
\text { brownfield regeneration processes [84]. }\end{array}$ & $\begin{array}{l}\text { Suggested use of SuRF-UK Framework } \\
\text { and guidance for sustainability } \\
\text { assessment in brownfields option } \\
\text { appraisal. }\end{array}$ \\
\hline Finland 2009 & $\begin{array}{l}\text { Review of Finnish Ministry Environment } \\
\text { guidance for risk assessment and } \\
\text { sustainable risk management, which } \\
\text { describes methods and indicators for } \\
\text { sustainability assessment and the } \\
\text { assessment process itself [85]. }\end{array}$ & $\begin{array}{l}\text { Made use of the SuRF-UK } 2009 \\
\text { indicators survey. }\end{array}$ \\
\hline Japan 2017-2018 & $\begin{array}{l}\text { Presentations made at SURF-Japan } \\
\text { Meetings, Tokyo, } 15 \text { and } 16 \text { May } 2018 \text { [86]. }\end{array}$ & $\begin{array}{l}\text { The SuRF-UK indicator guidance is being } \\
\text { used as a starting point for the } \\
\text { development of a sustainability criteria } \\
\text { checklist for use in Japan. }\end{array}$ \\
\hline Portugal 2013* & $\begin{array}{l}\text { A sustainability assessment was } \\
\text { undertaken relating to remedial works at } \\
\text { a marine fuel depot on the island of } \\
\text { Madeira. This was a 'live' assessment } \\
\text { undertaken at a decommissioned facility. } \\
\text { It represents a 'Stage B' assessment, } \\
\text { reviewing and comparing alternative } \\
\text { remediation options. }\end{array}$ & $\begin{array}{l}\text { The sustainability assessment followed } \\
\text { the SuRF-UK framework and included } \\
\text { use of its headline indicator categories. } \\
\text { Seven of the headline categories were } \\
\text { agreed as relevant for the site and the } \\
\text { others were weighted to zero. This } \\
\text { assessment was written up as a SuRF-UK } \\
\text { case study [42]. }\end{array}$ \\
\hline Netherlands $2017^{*}$ & $\begin{array}{l}\text { Review of sustainability assessment } \\
\text { development for remediation and a } \\
\text { selection of Dutch case studies [87]. }\end{array}$ & $\begin{array}{l}\text { Considers the use of the SuRF-UK } \\
\text { indicators from a Dutch perspective. }\end{array}$ \\
\hline OECD & $\begin{array}{l}\text { Strategic Considerations for the } \\
\text { Sustainable Remediation of Nuclear } \\
\text { Installations [88]. }\end{array}$ & $\begin{array}{l}\text { This report bases its sustainable } \\
\text { remediation definition on that of } \\
\text { SuRF-UK) and suggests a sustainability } \\
\text { management approach including } \\
\text { overview indicators. }\end{array}$ \\
\hline Poland 2015 & $\begin{array}{l}\text { A series of papers from a Polish } \\
\text { perspective about "social responsibility } \\
\text { and science in the innovation economy", } \\
\text { co-financed by the European Union under } \\
\text { the European Social Fund [89]. }\end{array}$ & $\begin{array}{l}\text { This wide-ranging series of papers } \\
\text { reviewed in detail the initial } 18 \text { headline } \\
\text { indicator categories from 2010, in the } \\
\text { context of soil threats. }\end{array}$ \\
\hline Portugal 2013 & $\begin{array}{l}\text { A sustainability framework for } \\
\text { redevelopment of rural brownfields: } \\
\text { stakeholder participation at } S \tilde{A O} \\
\text { DOMINGOS mine, Portugal [90]. }\end{array}$ & $\begin{array}{l}\text { The indicators suggested were based on a } \\
\text { wide-ranging review of indicators } \\
\text { considered relevant to brownfields } \\
\text { restoration including the SuRF-UK } \\
\text { Indicator set. }\end{array}$ \\
\hline Sweden 2015 & $\begin{array}{l}\text { Development of MCA tool Sustainable } \\
\text { Choice Of Remediation (SCORE) for } \\
\text { option appraisal, considering key criteria } \\
\text { in the economic, environmental and social } \\
\text { sustainability domains [65]. }\end{array}$ & $\begin{array}{l}\text { Linkage of the SuRF-UK indicators } \\
\text { concept to the same sustainability basis } \\
\text { used for SCORE. }\end{array}$ \\
\hline USA 2016/2017 & $\begin{array}{l}\text { Social equity is one of the three pillars of } \\
\text { sustainability. This report evaluates the } \\
\text { social sustainability of five remedial } \\
\text { alternatives for the Portland Harbor } \\
\text { Superfund Site. }\end{array}$ & $\begin{array}{l}\text { Application of the initial } 18 \text { headline } \\
\text { indicator categories from } 2010 \text { to } \\
\text { sustainability appraisal for a sediment } \\
\text { remediation project, and subsequently the } \\
2011 \text { set [91-94]. }\end{array}$ \\
\hline
\end{tabular}

* Work involving one or more of the authors of this paper. 


\section{Discussion}

The studies listed in Table 4 show that SuRF-UK indicator guidance has been used in its own right, or has been influential in the development of further indicator sets for sustainability assessment for remediation and brownfield applications in many countries around the world. Furthermore, it is often perceived as wide-ranging in its considerations, and balanced in terms of given consideration to the economic and social elements of sustainability as well as environmental indicators. This perception is in line with its designed purpose. A number of studies listed in Table 4 describe the lack of measurability of some of the indicator classes as problematic, in particular studies seeking quantitative metrics for sustainability assessment. SuRF-UK is fully aware that some individual indicator suggestions, and indeed some categories, may be hard to directly quantify. However, that does not invalidate them as being legitimate stakeholder concerns for sustainability, which are capable of comparison in qualitative assessment. They are also capable of comparison in semi-quantitative assessments, and even quantitatively in cost benefit assessment, for example, on the basis of surveys of opinions. There is a trade-off between scope and measurability, and SuRF-UK's approach is to start with qualitative assessment to allow for the widest possible scope, which is seen as a robust basis for sustainability assessment [95]. Different choices may be made in other countries where there is a preference for numbers and quantitative measures [9]. However, it is questionable whether quantitative methods provide greater reliability [23] rather than just 'comfort by numbers', and SuRF-UK benchmarking work indicates that they may not even be necessary for many sites [48].

A further criticism that has been raised in a few of the studies listed in Table 4 is that SuRF-UK indicator guidance is top-down, i.e., based on suggestions made by remediation experts and engineers. This is seen as being problematic in two ways, firstly that it may not sufficiently include discourse from Humanities disciplines, and secondly that, for the purposes of community engagement in sustainability assessment, may not be fully representatives of the "values" that impacted communities may wish to convey, or not be formulated in a way that community participants can readily engage with. Furthermore, interaction in describing and communicating values can be educational for both expert and non-expert alike and support constructive engagement [68,71,96-98]. This may be of great value for some particularly sensitive remediation projects. Nonetheless, land contamination may be used as "leverage" for a wider purpose by communities, for example objecting to housing developments. In this situation a constructive and open debate may not be that easy. On the other hand, a structured approach to sustainability assessment and a checklist of indicators may at least help to support structured and objective discussions.

The SuRF-UK indicator guidance is only intended as a checklist, to be developed and refined on a specific basis for each sustainability assessment, but their utility for community engagement is a valid concern. However, they do turn on the extent to which communities are actually influential in remediation decision making. This is highly site specific. SuRF-UK's framework [20] encourages appropriate stakeholder engagement, but leaves the decision on who to involve to the project management team [26], rather than make a prescriptive one-size-fits-all recommendation for all sites and all projects. This is in line with similar initiatives across the world and in line with the consequent 2017 ISO standard on sustainable remediation [14]. The general view is that it is those who are managing a project are best placed to decide who to involve in sustainability assessment, and both the ISO standard and SuRF-UK make clear that there is no absolute sustainable remediation metric. Hence, the sustainability assessment is essentially subjective, and so to be robust or persuasive it must encompass the inputs of relevant stakeholders who will be referring to it. It is also important to note that the SuRF-UK Framework is voluntary. It has an added value, for example in that (a) it can be persuasive to regulators in agreeing optimal remediation; (b) it optimises remedy selection and facilitates sustainability gains; and it can assist projects in being timelier to deliver and providing better value. However, it would be pointless to make a procedure for a voluntary approach so onerous that remediation practitioners would perceive that the burden of its execution would outweigh its potential benefits. SuRF-UK's position is therefore one of positive encouragement of broad and holistic 
sustainability assessment as a part of contaminated land risk management, rather than dictation of approach.

Community engagement is perhaps most likely to emerge as a vital step in brownfields projects where restoration is centred on some form of public utility, for example as a park, and/or where there is a substantial public investment in the restoration/remediation work to be carried out. An example of such a project is the Port Sunlight Riverside Park (PSRP) by the Land Trust, mentioned in Table 2, where the value of the park to different public constituencies played a major part both in the investment case made to support the project, and in understanding its sustainability benefits [45]. While the sustainability assessment work carried out so far does not yet include widespread stakeholder engagement, it is already evident that there are some significant "missing" items in the social element of the SuRF-UK indicator guidance, namely: cultural impacts and public health. For the PSRP project these are seen as major benefits. While, the SuRF-UK Framework allows for addition of site-specific indicators, it is perhaps fair to argue that these could be important additions to the general checklist. It might also be fair to argue that the indicators have largely derived from discussion of the remediation of operational sites, or brownfield sites for built redevelopment, as this represented the broad initial interests of the SuRF-UK constituency.

\section{Conclusions}

The key findings of this review are that the SuRF-UK framework and indicator guidance is well adopted into practice in the UK, where it is widely recognised as the most appropriate mechanism to support sustainability-based decision making in contaminated land decision making. It has also influenced the development of national and international guidance and standards on sustainable remediation. However, there is room for some fine tuning of the approach and details, based on the lessons learned during its application. Broadly speaking, the SuRF-UK indicator guidance has achieved its aim of encouraging sustainable remediation decision making to adopt a broad scope for sustainability indicators or criteria in the UK. Its aims in achieving better sustainable management of land is also fully in line with the recently published UK Government 25-year-plan "to improve the environment" [99].

The indicator guidance has exceeded its authors' expectations in terms of the international influence that it has had. Since the publication of this checklist in 2011, there has been a significant number of indicator publications in brownfields and remediation domains worldwide. There has also been some constructive critical assessment of the SuRF-UK indicator guidance in the international peer-reviewed literature, and there has been a growing body of experience in its use in practice, both for operational and built development sites, and for soft (non-built) re-use of brownfields. This practical use has revealed some potential opportunities for improvement. Consequently, over 2018, SuRF-UK is planning to review and benchmark its indicator guidance against publications since 2011, and overhaul its checklist accordingly. This will be combined with a UK consultation exercise and an open invitation for comment to other sustainable remediation networks around the world that take part in ISRA.

Author Contributions: The principal drafting author is R.P.B., with major contributions from H.F.T., J.W.N.S. and N.D.H. Other authors have provided intellectual input through SuRF-UK development, and peer-review comments of the draft manuscript.

Acknowledgments: The drafting of this paper was generously supported by Shell Global Solutions. However, its content is based on work that has been funded, either by financial or in-kind contributions from all members of the SuRF-UK Steering Group on the basis of both corporate and personal inputs. Shell Global Solutions also provided funding for Open Access to this article.

Conflicts of Interest: For the sake of completeness we state here all relevant affiliations. However, this paper represents only the individual views of the authors and does not necessarily reflect the opinions of their employing organisations. Co-authors of this work are employed by Shell Global Solutions, National Grid plc and the Homes and Community Agency (now Homes England), which have each provided funding to support SuRF-UK. Shell Global Solutions provided funding to RPB for the preparation of this paper. Frank Evans (National Grid plc) acted as SuRF-UK's chairperson from 2007-2010. Jonathan Smith held that role from 2010-2017 and Hayley Thomas is co-Chair (with RPB) 2017-current. 


\section{References}

1. Ernst \& Young. Evaluation of Expenditure and Jobs for Addressing Soil Contamination in Member States; Final Report to the European Commission, Directorate-General Environment; Reference: ENV.B.1/ETU/2011/0012. 2013. Available online: http:/ / ec.europa.eu/environment/soil/pdf/Soil_contamination_expenditure_jobs.pdf (accessed on 19 March 2018).

2. National Research Council. Alternatives for Managing the Nation's Complex Contaminated Groundwater Sites; The National Academies Press: Washington, DC, USA, 2013.

3. Boots, B. Global Markets for Environmental Remediation Technologies. Code ENV006C. October 2017. Available online: www.bccresearch.com/market-research/environment/global-markets-for-environmentalremediation-technologies-env006c.html (accessed on 19 March 2018).

4. Ferguson, C.; Darmendrail, D.; Freier, K.; Jensen, B.K.; Jensen, J.; Kasamas, H.; Urzelai, A.; Vegter, J. (Eds.) Risk Assessment for Contaminated Sites in Europe; Final Publication; LQM Press: Nottingham, UK, 1998; Volume 1 Scientific Basis; ISBN 0953309002.

5. Nathanail, C.P.; Bardos, R.P.; Gillett, A.; McCaffrey, C.; Ogden, R.; Scott, D.; Nathanail, J. International Processes for Identification and Remediation of Contaminated Land; SP1004 SID 5; Report for Department Environment Food and Rural Affairs (DEFRA); DEFRA: London, UK, 2013. Available online: http:/ / randd.defra.gov.uk/ Default.aspx?Menu=Menu\&Module=More\&Location=None\&Completed=0\&ProjectID=16289 (accessed on 19 March 2018).

6. Swartjes, F.A. (Ed.) Dealing with Contaminated Sites: From Theory towards Practical Application; Springer: Dordrecht, The Netherlands, 2011.

7. Vegter, J.; Lowe, J.; Kasamas, H. (Eds.) Sustainable Management of Contaminated Land: An Overview; 2002 on Behalf of CLARINET; Austrian Federal Environment Agency: Wien, Austria, 2002; Available online: www. commonforum.eu/references_clarinet.asp (accessed on 19 March 2018).

8. Hadley, P.; Ellis, D. Sustainable remediation white paper-Integrating sustainable principles, practices, and metrics into remediation projects. Remediat. J. 2009, 19, 5-114.

9. Rizzo, E.; Bardos, P.; Pizzol, L.; Critto, A.; Giubilato, E.; Marcomini, A.; Albano, C.; Darmendrail, D.; Döberl, G.; Harclerode, M.; et al. Comparison of international approaches to sustainable remediation. J. Environ. Manag. 2016, 184, 4-17. [CrossRef] [PubMed]

10. Nathanail, C.P.; Bakker, L.M.M.; Bardos, P.; Furukawa, Y.; Nardella, A.; Smith, G.; Smith, J.W.M.; Goetsche, G. Towards an international standard: The ISO/DIS 18504 standard on sustainable remediation. Remediat. J. 2017, 28, 9-15. [CrossRef]

11. Interstate Technology and Regulatory Council (ITRC). Green and Sustainable Remediation: State of the Science and Practice. 2011. Available online: http:/ / www.itrcweb.org/GuidanceDocuments/GSR-1.pdf (accessed on 19 March 2018).

12. ITRC. Green and Sustainable Remediation: A Practical Framework. Available online: http://www.itrcweb. org/GuidanceDocuments/GSR-2.pdf2011 (accessed on 19 March 2018).

13. ASTM International. Standard Guide for Integrating Sustainable Objectives into Cleanup; ASTM E2876-13; ASTM International: West Conshohocken, PA, USA, 2013; Available online: www.astm.org/Standards/E2876.htm (accessed on 19 March 2018).

14. International Organization for Standardization (ISO). Soil Quality—Sustainable Remediation. ISO 18504:2017. Available online: www.iso.org/standard/62688.html (accessed on 19 March 2018).

15. Singh, R.K.; Murty, H.R.; Gupta, S.K.; Dikshit, A.K. An overview of sustainability assessment methodologies. Ecol. Indic. 2009, 9, 189-212. [CrossRef]

16. World Resources Institute. The World Resources Institute's Sustainability Initiative. Available online: www.wri.org/sustainability-wri (accessed on 19 March 2018).

17. CL:AIRE. SuRF-UK Framework Annex 1: The SuRF-UK Indicator Set for Sustainable Remediation Assessment. 2011. Available online: www.claire.co.uk/surfuk (accessed on 19 March 2018).

18. United Nations World Commission on Environment and Development. Our Common Future; The Brundtland Report; Oxford University Press: Oxford, UK, 1987; ISBN 019282080 X.

19. CL:AIRE. Meetings, Presentations and Consultations; SuRF-UK; CL:AIRE: London, UK, 2007; Available online: www.claire.co.uk/projects-and-initiatives/surf-uk/80-meetings-presentations-and-consultations (accessed on 19 March 2018). 
20. CL:AIRE. A Framework for Assessing the Sustainability of Soil and Groundwater Remediation (SuRF-UK). Available online: www.claire.co.uk/surfuk (accessed on 19 March 2018).

21. NICOLE. Sustainable Remediation Working Group Report; NICOLE Secretariat: Appeldoorn, The Netherlands, 2012; Available online: www.nicole.org/pagina/22/Thematic_Documents.html (accessed on 19 March 2018).

22. Bardos, P.; Bakker, L.; Slenders, H.; Nathanail, P. Sustainable Remediation. In Dealing with Contaminated Sites: From Theory towards Practical Application; Swartjes, F.A., Ed.; Springer: Dordrecht, The Netherlands, 2011; pp. 889-948, ISBN 978-90-481-9756-9.

23. Bardos, R.P.; Bone, B.D.; Boyle, R.; Evans, F.; Harries, N.; Howard, T.; Smith, J.W.N. The rationale for simple approaches for sustainability assessment and management in contaminated land practice. Sci. Total Environ. 2016, 563-564, 755-768. [CrossRef] [PubMed]

24. Ackermann, F. Critique of Cost-Benefit Analysis, and Alternative Approaches to Decision-Making; A Report to Friends of the Earth England, Wales and Northern Ireland. 2008. Available online: https: / / friendsoftheearth.uk/sites/default/files/downloads/policy_appraisal.pdf (accessed on 19 March 2018).

25. HM Treasury. The Green Book: Appraisal and Evaluation in Central Government. Revised 2011. Available online: www.gov.uk/government/publications/the-green-book-appraisal-and-evaluation-in-central-governent (accessed on 19 March 2018).

26. CL:AIRE. The SuRF-UK Bulletin 4; CL:AIRE: London, UK, 2014; Available online: www.claire.co.uk/surfuk (accessed on 19 March 2018).

27. CL:AIRE. Sustainable Management Practices for Management of Land Contamination; CL:AIRE: London, UK, 2014; Available online: www.claire.co.uk/surfuk (accessed on 19 March 2018).

28. Smith, S.; Richardson, J.; McNab, A.; Wilson, S. Towards a More Efficient and Effective Use of Strategic Environmental Assessment and Sustainability Appraisal in Spatial Planning; Final Report for Department for Communities and Local Government; DCLG: London, UK, 2010.

29. U.S. Environmental Protection Agency. Green Remediation: Incorporating Sustainable Environmental Practices into Remediation of Contaminated Sites; EPA/542/R/08/002; U.S. Environmental Protection Agency: Washington, DC, USA, 2008.

30. CL:AIRE. In A Review of Published Sustainability Indicator Sets: How Applicable Are They to Contaminated Land Remediation Indicator-Set Development? CL:AIRE: London, UK, 2009; ISBN 978-1-905046-18-8. Available online: www.claire.co.uk/surfuk (accessed on 19 March 2018).

31. FAO. Voluntary Guidelines for Sustainable Soil Management; Food and Agriculture Organization of the United Nations: Rome, Italy, 2017; Available online: http://www.fao.org/3/a-bl813e.pdf (accessed on 19 March 2018).

32. European Commission. Report from the Commission to the European Parliament, the Council, the European Economic and Social Committee and the Committee of the Regions. The Implementation of the Soil Thematic Strategy and Ongoing Activities COM/2012/046 Final. Available online: http:/ / eur-lex.europa.eu/legalcontent/EN/ALL/?uri=CELEX:52012DC0046 (accessed on 19 March 2018).

33. Department for Environment, Food and Rural Affairs (DEFRA). Soil Strategy for England. Available online: www.gov.uk/government/publications/safeguarding-our-soils-a-strategy-for-england (accessed on 19 March 2018).

34. Institute for Advanced Sustainability Studies. Grounding the Post-2015 Development Agenda: Options for the Protection of Our Precious Soil and Land Resources; Policy Brief; IASS: Potsdam, Germany, 2015; Available online: http:/ / publications.iass-potsdam.de/pubman/faces/viewItemOverviewPage.jsp?itemId= escidoc:1015902:3 (accessed on 19 March 2018).

35. European Commission. Roadmap to a Resource Efficient Europe. $\operatorname{COM}(2011)$ 571. 2011. Available online: http:/ / ec.europa.eu/environment/resource_efficiency/about/roadmap/index_en.htm (accessed on 19 March 2018).

36. European Environment Agency. Land Recycling in Europe Approaches to Measuring Extent and Impacts; EEA Report No 31/2016; European Environment Agency: Copenhagen, Denmark, 2016.

37. Environment Agency. Managing and Reducing Land Contamination: Guiding Principles (GPLC2_FAQs, Technical Information, Detailed Advice and References). Available online: www.gov.uk/government/ publications/managing-and-reducing-land-contamination (accessed on 19 March 2018). 
38. CL:AIRE. Petroleum Hydrocarbons in Groundwater: Guidance on Assessing Petroleum Hydrocarbons Using Existing Hydrogeological Risk Assessment Methodologies. 2017. Available online: https:/ / www.claire.co.uk/component/phocadownload/category/22-important-industry-documents? download=573: petroleum-hydrocarbons-in- groundwater-guidance (accessed on 19 March 2018).

39. Department for Communities and Local Government. National Planning Policy Framework. Available online: https:/ /www.gov.uk/government/uploads/system/uploads/attachment_data/file/6077/2116950.pdf (accessed on 19 March 2018).

40. Ministry of Housing, Communities and Local Government. National Planning Policy Framework. Consultation Proposals. 2018. Available online: https://www.gov.uk/government/consultations/draftrevised-national-planning-policy-framework (accessed on 19 March 2018).

41. Welsh Government. Consultation Document. Draft Planning Policy Wales: Edition 10. 2018. Available online: https:/ / beta.gov.wales/planning-policy-wales-edition-10 (accessed on 19 March 2018).

42. CL:AIRE. Sustainability Assessment: Shell Terminal Facility, Madeira. Bulletin SuRF 1. 2013. Available online: https:/ / www.claire.co.uk/projects-and-initiatives/surf-uk/22-supporting-materials/95-surf-ukcase-studies-and-bulletins (accessed on 19 March 2018).

43. CL:AIRE. Sustainability Assessment: Upper Heyford-Remediation Options Appraisal. Bulletin SuRF-UK. Bulletin SURF 2. 2013. Available online: https:/ / www.claire.co.uk/projects-and-initiatives/surf-uk/22supporting-materials /95-surf-uk-case-studies-and-bulletins (accessed on 19 March 2018).

44. CL:AIRE. Sustainability Assessment: Helpston Contaminated Land Project. Bulletin SuRF-UK. Bulletin SURF 3. 2013. Available online: https:/ / www.claire.co.uk/projects-and-initiatives/surf-uk/22-supportingmaterials/95-surf-uk-case-studies-and-bulletins (accessed on 19 March 2018).

45. Li, X.; Bardos, P.; Cundy, A. Sustainability of Brownfield Regeneration for Soft Reuse: A Case Study of Port Sunlight River Park (PSRP); Summary Report; Report Produced for Land Trust, Warrington, UK; University of Brighton: Brighton, UK, 2017.

46. Bardos, P.; Merly, C.; Bardos, A.; Bone, B.; Bartke, S.; Harries, N.; Gillett, A.; Nathanail, J.; Nathanail, P.; Gens, A.; et al. Taking Nanotechnological Remediation Processes from Lab Scale to End User Applications for the Restoration of a Clean Environment WP9: Dissemination, Dialogue with Stakeholders and Exploitation DL9.2 Final Exploitation Strategy, Risk Benefit Analysis and Standardisation Status. NanoRem Deliverable, European Union Seventh Framework Programme Project, Grant Agreement n 309517. 2016. Available online: www.nanorem.eu (accessed on 19 March 2018).

47. Gill, R.T.; Thornton, S.F.; Harbottle, M.J.; Smith, J.W.N. Sustainability assessment of electrokinetic bioremediation compared with alternative remediation options for a petroleum release site. J. Environ. Manag. 2016, 184, 120-131. [CrossRef] [PubMed]

48. Smith, J.W.M.; Kerrison, G. Benchmarking of Decision-Support Tools Used for Tiered Sustainable Remediation Appraisal. Water Air Soil Pollut. 2013, 224, 1706. [CrossRef] [PubMed]

49. Hou, D.; Al-Tabbaa, A.; Guthrie, P.; Hellings, J.; Gu, Q. Using a hybrid LCA method to evaluate the sustainability of sediment remediation at the London Olympic Park. J. Clean. Prod. 2014, 83, 87-95. [CrossRef]

50. United Nations. Transforming Our World: The 2030 Agenda for Sustainable Development; A/RES/70/1. 2015. Available online: www.un.org/en/development/desa/population/migration/generalassembly/ docs/globalcompact/A_RES_70_1_E.pdf (accessed on 23 March 2018).

51. Dixon, T.; Pocock, Y.; Waters, M. The Role of the UK Development Industry in Brownfield Regeneration. Stage 2 Report Volume 2 (of 3): Sub-Regional Context (Thames Gateway and Greater Manchester). 2005. Available online: www.ucem.ac.uk/wp-content/uploads/2016/01/brownfieldvol2.pdf (accessed on 19 March 2018).

52. Gould, K.A.; Lewis, T.L. Green Gentrification Urban sustainability and the Struggle for Environmental Justice; Routledge: Abingdon-on-Thames, UK, 2017; ISBN 9781138309135.

53. Bardos, R.P.; Bone, B.D.; Andersson-Sköld, Y.; Suer, P.; Track, T.; Wagelmans, M. Crop-Based Systems for Sustainable Risk-Based Land Management for Economically Marginal Damaged Land. Remediat. J. 2011, 21, 11-33. [CrossRef]

54. CL:AIRE. The Definition of Waste: Development Industry Code of Practice; CL:AIRE: London, UK, 2011; ISBN 978-1-905046-23-2. Available online: www.claire.co.uk/projects-and-initiatives/dow-cop (accessed on 19 March 2018). 
55. US Environmental Protection Agency. Renewable Energy on Contaminated Lands: Mine Sites, Landfills, Brownfields, Superfund, RCRA, etc. 2008. Available online: https:/ /www.epa.gov/land-revitalization/renewableenergy-contaminated-lands-mine-sites-landfills-brownfields-superfund (accessed on 19 March 2018).

56. Cárdenas Giraldo, J.A.; Ryan, L.; Prutthisathaporn, M.; Joshi, N.; Sato, Y. Evidence of Economic Impact of Port Sunlight River Park. Report Date: 24th November 2017. Available online: https://thelandtrust.org.uk/wpcontent/uploads/2018/02/Manchester-Business-School-MBA-Consultancy-project-Final-report.pdf (accessed on 19 March 2018).

57. OECD. Better Life Index. Available online: www.oecdbetterlifeindex.org (accessed on 19 March 2018).

58. Chrysochooua, M.; Browna, K.; Dahala, G.; Granda-Carvajalb, C.; Segersonb, K.; Garricka, N.; Bagtzogloua, A. A GIS and indexing scheme to screen brownfields for area-wide redevelopment planning. Landsc. Urban Plan. 2012, 105, 187-198. [CrossRef]

59. Schädler, S.; Finkel, M.; Bleicher, A.; Morio, M.; Gross, M. Spatially explicit computation of sustainability indicator values for the automated assessment of land-use options. Landsc. Urban Plan. 2013, 111, $34-45$. [CrossRef]

60. Agostini, P.; Pizzol, L.; Critto, A.; D'Alessandro, M.; Zabeo, A.; Marcomini, A. Regional risk assessment for contaminated sites Part 3: Spatial decision support system. Environ. Int. 2012, 48, 121-132. [CrossRef] [PubMed]

61. Pizzol, L.; Zabeo, A.; Klusáček, P.; Giubilato, E.; Critto, A.; Frantal, B.; Martinat, S.; Kunc, J.; Osman, R.; Bartke, S. Timbre Brownfield Prioritization Tool to support effective brownfield regeneration. J. Environ. Manag. 2016, 166, 178-192. [CrossRef] [PubMed]

62. Schädler, M.; Morio, S.; Bartke, S.; Rohr-Zänker, R.; Finkel, M. Designing sustainable and economically attractive brownfield revitalization options using an integrated assessment model. J. Environ. Manag. 2011, 92, 827-837. [CrossRef] [PubMed]

63. Huysegoms, L.; Rousseau, S.; Cappuyns, V. Friends or foes? Monetized Life Cycle Assessment and Cost-Benefit Analysis of the site remediation of a former gas plant Lies. Sci. Total Environ. 2018, 619-620, 258-271. [CrossRef] [PubMed]

64. An, D.; Xi, B.; Wang, Y.; Xu, D.; Tang, J.; Dong, L.; Ren, J.; Pang, C. A sustainability assessment methodology for prioritizing the technologies of groundwater contamination remediation. J. Clean. Prod. 2016, 112, 4647-4656. [CrossRef]

65. Doberl, G.; Ortmann, M.; Fruhwirth, W. Introducing a goal-oriented sustainability assessment method to support decision making in contaminated site management. Environ. Sci. Policy 2013, 25, 207-217. [CrossRef]

66. Söderqvist, T.; Brinkhoff, P.; Norberg, T.; Rosén, L.; Back, P.-E.; Norrman, J. Cost-benefit analysis as a part of sustainability assessment of remediation alternatives for contaminated land. J. Environ. Manag. 2015, 157, 267-278. [CrossRef] [PubMed]

67. Butler, P.B.; Larsen-Hallock, L.; Lewis, R.; Glenn, C.; Armstead, R. Metrics for integrating sustainability evaluations into remediation projects. Remediat. J. 2011, 21, 81-87. [CrossRef]

68. Plant, R.; Boydell, S.; Prior, J.; Chong, J.; Lederwasch, A. From liability to opportunity: An institutional approach towards value-based land remediation. Environ. Plan. C Politics Space 2016, 35, 197-220. [CrossRef]

69. Hunt, J.W.; Smith, G.J. Applying sustainable remediation principles in Australasia. Remediat. Aust. 2015, 16-20. Available online: http:/ / www.crccare.com/files/dmfile/RemediationAustralasiaIssue17.pdf (accessed on 24 May 2018).

70. Smith, G.; Nadebaum, P. The evolution of sustainable remediation in Australia and New Zealand: A storyline. J. Environ. Manag. 2016, 184, 27-35. [CrossRef] [PubMed]

71. Hughes, K. Do remediation experts have what it takes to explain empirical uncertainty? Remediat. J. 2017, 28, 73-86. [CrossRef]

72. Beames, A.; Broekx, S.; Lookman, R.; Touchant, K.; Seuntjens, P. Sustainability appraisal tools for soil and groundwater remediation: How is the choice of remediation alternative influenced by different sets of sustainability indicators and tool structures? Sci. Total Environ. 2014, 470-471, 954-966. [CrossRef] [PubMed]

73. Cappuyns, V. Inclusion of social indicators in decision support tools for the selection of sustainable site remediation options. J. Environ. Manag. 2016, 184, 45-56. [CrossRef] [PubMed]

74. Huysegoms, L.; Cappuyns, V. Critical review of decision support tools for sustainability assessment of site remediation options. J. Environ. Manag. 2017, 196, 278-296. [CrossRef] [PubMed] 
75. Bueno, F.B.; Günther, W.M.R.; Philippi, A. Sustainable Management for a Contaminated Area on Campus. In Handbook of Theory and Practice of Sustainable Development in Higher Education; Leal Filho, W., Azeiteiro, U., Alves, F., Molthan-Hill, P., Eds.; World Sustainability Series; Springer: Cham, Switzerland, 2017; ISBN 978-3-319-47877-7.

76. Zhao, X. Contaminated land remediation: Legal issues and recommendations for China. In Developing an Appropriate Contaminated Land Regime in China; Springer: Berlin/Heidelberg, Germany, 2013.

77. Coulon, F.; Bardos, P.; Harries, N.; Canning, K.; Chen, M.; Hu, Q.; Jones, K.; Li, F.; Li, H.; Gomes, D.; et al. Land Contamination and Brownfield Management Policy Development in China: Learning from the UK Experience; China UK Partnership for Contaminated Land Management: Cranfield, UK, 2016; Available online: http:/ / cnukcontaminatedland.com/uk/downloads (accessed on 19 March 2018).

78. Hou, D.; Ding, Z.; Li, G.; Wu, L.; Hu, P.; Guo, G.; Wang, X.; Ma, Y.; O'Connor, D.; Wang, X. A sustainability assessment framework for agricultural land remediation in China. Land Degrad. Dev. 2017, 29. [CrossRef]

79. Song, Y.; Hou, D.; Zhang, J.; O'Connor, D.; Li, G.; Gu, Q.; Li, S.; Liu, P. Environmental and socio-economic sustainability appraisal of contaminated land remediation strategies: A case study at a mega-site in China. Sci. Total Environ. 2018, 610-611, 391-401. [CrossRef] [PubMed]

80. Bardos, P.; Cundy, A.; Maco, B.; Kovalick, W.; Rodríguez, A.; Hutchings, A.; Hall, E.; Rodríguez, A. Strategies for Rehabilitating Mercury-Contaminated Mining Lands for Renewable Energy and Other Self-Sustaining Re-Use Strategies. 2017. Available online: http:/ /www.r3environmental.com.co/en/projects.html (accessed on 19 March 2018).

81. NICOLE. Road Map for Sustainable Remediation (Co-Author); NICOLE Secretariat: Appeldoorn, The Netherlands, 2011; Available online: www.nicole.org/pagina/22/Thematic_Documents.html (accessed on 19 March 2018).

82. Søndergaard, G.L.; Binning, P.J.; Bjerg, P.L. Approaches for assessing sustainable remediation. In Proceedings of the 6th Joint Nordic Meeting of Remediation of Contaminated Sites (NORDROCS 2016), Espoo, Finland, 5-8 September 2016.

83. Søndergaard, G.L.; Binning, P.J.; Bondgaard, M.; Bjerg, P.L. Multi-criteria assessment tool for sustainability appraisal of remediation alternatives for a contaminated site. J. Soils Sediments 2017. [CrossRef]

84. Bardos, P.; Jones, S.; Stephenson, I.; Menger, P.; Beumer, V.; Neonato, F.; Maring, L.; Ferber, U.; Track, T.; Wendler, K. Optimising Value from the Soft Re-use of Brownfield Sites. Sci. Total Environ. 2016, 563-564, 769-782. [CrossRef] [PubMed]

85. Reinikainen, J.; Sorvari, J.; Tikkanen, S. Finnish policy approach and measures for the promotion of sustainability in contaminated land management. J. Environ. Manag. 2016, 184, 108-119. [CrossRef] [PubMed]

86. Yasutaka, T.; Furukawa, Y.; Nakashima, M.; SURF-Japan, Secretariat AIST, Tokyo, Japan. Personal communication, 16 May 2018.

87. Slenders, H.L.A.; Bakker, L.; Bardos, P.; Verburg, R.; Alphenaar, A. There Are More than Three Reasons to Consider Sustainable Remediation, a Dutch Perspective. Remediat. J. 2017, 27, 77-97. [CrossRef]

88. The Organisation for Economic Co-operation and Development (OECD); Nuclear Energy Agency. Strategic Considerations for the Sustainable Remediation of Nuclear Installations; OECD: Paris, France, 2016.

89. Doula, M.K. Soil: Threats and Protection. Sustainable Agriculture. In Social Responsibility and Science in Innovation Economy; Kawalec, P., Wierzchoslawski, R.P., Eds.; Wydawnictwo KUL: Lublin, Poland, 2015; pp. 193-272, ISBN 978-83-8061-147-4.

90. Sardinha, I.D.; Craveiro, D.; Milheiras, S. A sustainability framework for redevelopment of rural brownfields: Stakeholder participation at São Domingos mine, Portugal. J. Clean. Prod. 2013, 57, 200-208. [CrossRef]

91. Fitzpatrick, A.G.; Apitz, S.E.; Harrison, D.; Ruffle, B.; Edwards, D.A. The Portland Harbor Superfund Site Sustainability Project: Introduction. Integr. Environ. Assess. Manag. 2018, 14, 17-21. [CrossRef] [PubMed]

92. Apitz, S.E.; Fitzpatrick, A.G.; McNally, A.; Harrison, D.; Coughlin, C.; Edwards, D.A. Stakeholder Value-Linked Sustainability Assessment: Evaluating Remedial Alternatives for the Portland Harbor Superfund Site, Portland, Oregon, USA. Integr. Environ. Assess. Manag. 2018, 14, 43-62. [CrossRef] [PubMed]

93. McNally, A.D.; Fitzpatrick, A.G.; Mirchandani, S.; Salmon, M.; Edwards, D.A. CERCLA-Linked Environmental Impact and Benefit Analysis: Evaluating Remedial Alternatives for the Portland Harbor Superfund Site, Portland, Oregon, USA. Integr. Environ. Assess. Manag. 2018, 14, 22-31. [CrossRef] [PubMed]

94. SEA Environmental Decisions Ltd.; AECOM. Portland Harbor Sustainability Project: Evaluation of EPA Portland Harbor Superfund Site Remedial Alternatives; Social Analysis Report Prepared for: The Portland Harbor Superfund Site Sustainability Project; SEA Environmental Decisions Ltd.: Hertfordshire, UK, 2016. 
95. Bardos, R.P.; Bone, B.D.; Boyle, R.; Ellis, D.; Evans, F.; Harries, N.; Smith, J.W.N. Applying Sustainable Development Principles to Contaminated Land Management Using the SuRF-UK Framework. Remediat. J. 2011, 21, 77-100. [CrossRef]

96. Prior, J.; Rai, T. Engaging with residents' perceived risks and benefits about technologies as a way of resolving remediation dilemmas. Sci. Total Environ. 2017, 601-602, 1649-1669. [CrossRef] [PubMed]

97. Harclerode, M.A.; Lal, P.; Vedwan, N.; Wolde, B.; Miller, M.E. Evaluation of the role of risk perception in stakeholder engagement to prevent lead exposure in an urban setting. J. Environ. Manag. 2016, 184, 132-142. [CrossRef] [PubMed]

98. Ridsdale, D.R.; Noble, B.F. Assessing sustainable remediation frameworks using sustainability principles. J. Environ. Manag. 2016, 184, 36-44. [CrossRef] [PubMed]

99. HM Government. A Green Future: Our 25 Year Plan to Improve the Environment. 2018. Available online: www.gov.uk/government/publications/25-year-environment-plan (accessed on 23 March 2018).

(C) 2018 by the authors. Licensee MDPI, Basel, Switzerland. This article is an open access article distributed under the terms and conditions of the Creative Commons Attribution (CC BY) license (http://creativecommons.org/licenses/by/4.0/). 